\title{
Significant linkage disequilibrium between the Huntington's disease locus and markers at loci D4S10, D4S95, and D4S111 in Northern Ireland
}

\author{
P J Morrison, C A Graham, N C Nevin
}

\begin{abstract}
An analysis of the Northern Ireland Huntington's disease (HD) population of 75 families showed significant linkage disequilibrium between the HD gene and DNA markers at D4S95, D4S10, and D4S111. As the linkage disequilibrium at loci D4S10 and D4S111 is different from previous studies in the UK, but similar at locus D4S95, this suggests either that the HD mutation(s) in the Northern Ireland and British populations is not of common origin or that the haplotype of the common HD mutation has changed over time subsequent to divergence from a common origin.

(F Med Genet 1993;30:1018-19)
\end{abstract}

HD is a progressive neurodegenerative autosomal dominant disorder with movement, cognitive, and psychiatric dysfunction. Recent research has shown that the condition is caused by expansion of a trinucleotide repeat (CAG)n in the IT 15 gene. ${ }^{1}$ As the clinical onset of HD is later in life, there has been difficulty in genetically defining clinically unaffected subjects in families. This had made haplotyping and conventional linkage studies difficult and at times misleading. Alternative methods were used to help localise the HD gene, including linkage disequilibrium. Significant linkage disequilibrium has been shown between the HD

\begin{tabular}{lc} 
Table 1 & PCR cycle settings. \\
\hline $\mathrm{G} 8$ & $5^{\prime}\left(994^{\circ} \mathrm{C} 31 \times\left(1^{\prime}\left(a 94,1^{\prime}(a) 56,0 \cdot 5^{\prime}(a) 72\right)\right.\right.$ \\
Kp1.65 & $4^{\prime}\left(a 95^{\circ} \mathrm{C} 1 \times\left(1^{\prime}\left(a 95,1^{\prime}\left(a 58,0 \cdot 5^{\prime}(a 72)\right.\right.\right.\right.$ \\
& $30 \times\left(1^{\prime}\left(a 95,2^{\prime}\left(a 55,1^{\prime}(a 72)\right.\right.\right.$ \\
IDUA & $5^{\prime}\left(a 95^{\circ} \mathrm{C} 30 \times\left(0^{\circ} 5^{\prime}\left(a 95,0^{\prime} \cdot 7^{\prime}\left(a 66,0 \cdot 7^{\prime}(a 72)\right.\right.\right.\right.$ \\
157.9 & $7^{\prime}\left(a 96^{\circ} \mathrm{C} 30 \times\left(0^{\circ} 5^{\prime}\left(a 95,7^{\prime}\left(a 65,1 \cdot 5^{\prime}(a 72)\right.\right.\right.\right.$ \\
YNZ32 & $5^{\prime}\left(a 95^{\circ} \mathrm{C} 10 \times\left(1^{\prime}\left(a 94,2^{\prime}\left(a 65,3^{\prime}(a) 72\right) ;\right.\right.\right.$ \\
& $15 \times\left(1^{\prime}\left(a 94,2^{\prime}\left(a 60,3^{\prime}(a 72) ;\right.\right.\right.$ \\
& $5 \times\left(1^{\prime}\left(a 94,2^{\prime}\left(a 57,3^{\prime}(a 72)\right.\right.\right.$ \\
\hline
\end{tabular}

Department of Medical Genetics, The Queen's University of Belfast, Floor A.

Belfast City Hospital, Lisburn Road, Belfast BT9 7AB, Northern

Ireland.

P J Morrison

C A Graham

N C Nevin

Correspondence to

Dr Morrison.

Received 22 March 1993.

Revised version accepted 5 August 1993.
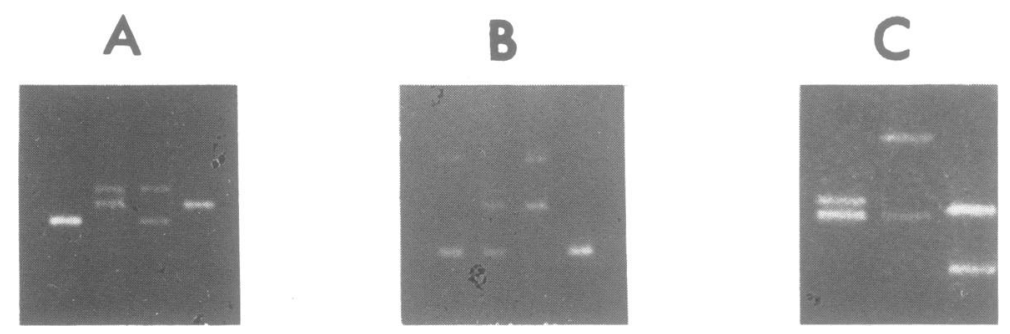

Figure 1 Multiallelic PCR markers used in this study visualised by ethidium bromide staining in agarose gels. Gel $A(1 \cdot 2 \%$ BRL agarose) shows 157.9 (D4S111) with alleles at 630,715 , and $800 \mathrm{bp}$. Gel B (1\% Nusieve, $1 \%$ BRL agarose $)$ shows Kpl1.65 (D4S43) with alleles at 184, 268, and $338 \mathrm{bp}$. Gel C (1.2\% agarose) shows YNZ32 (D4S125) with the largest allele $\sim 2 \mathrm{~kb}$. gene, the locus D4S95, and other markers. ${ }^{2-10}$ In Northern Ireland, 75 unrelated HD families were analysed with several markers in the HD gene region (4p16.3-pter).

\section{Materials and methods}

DNA was extracted using either an automated DNA extractor (Applied Biosystems, USA) or manually. ${ }^{11}$ Southern blot analysis was carried out on the genomic DNA for the D4S95 locus. ${ }^{12}$ Polymerase chain reaction (PCR) was used to analyse five multiallelic markers: IDUA at locus D4S111, ${ }^{13}$ YNZ32 at locus D4S125 (the fragments obtained were not further digested), ${ }^{14} 157.9$ at locus D4S $111,{ }^{15}$ Kp1.65 at locus D4S43, ${ }^{16}$ and G8 at locus D4S10. ${ }^{17}$ The PCR cycles used are shown in table 1. Multiallelic PCR products are shown in fig 1 . Using the original primer sequences, ${ }^{18}$ the PCR product from probe $\mathrm{G} 8$ was digested with HindIII to show the HindIII site 1 polymorphism, giving band sizes of $93 \mathrm{bp}$ (undigested) and $59 \mathrm{bp}$ (digested).

For the allele frequency study, samples from clinically affected HD patients were used. Phase was determined by typing affected HD patients and their parents. DNA markers for normal chromosomes were determined by typing spouses of HD families where possible. All patients sampled had Northern Ireland ancestry. Linkage disequilibrium was calculated using a $\chi^{2}$ statistic with Yates's correction.

\section{Results}

Table 2 shows the linkage disequilibrium data for HD and normal chromosomes. Highly significant results were obtained with the markers D4S10/G8/HindIII ( $p=0.0006), \quad \mathrm{D} 4$ S95/ p674/MboI ( $\mathrm{p}=0.0063)$, and D4S111/IDUA/ $K p n \mathrm{I}(\mathrm{p}=0.0047)$. Other markers, including D4S95/p674/TaqI, did not show significance. Fig 2 shows the location of probes used on chromosome $4 .^{19}$

\section{Discussion}

In this study linkage disequilibrium has been detected at loci D4S10, D4S95, and D4S111 in the HD patient group. Previous studies from the $\mathrm{UK}^{2-4}$ and in Canadian families with British ancestry, ${ }^{5}$ have shown significant linkage disequilibrium at D4S95 but not at $\mathrm{D} 4 \mathrm{~S} 10$. The region around D4S95 shows consistent linkage disequilibrium in all popula- 
Table 2 Distribution of alleles for the markers D4S10, D4S125, D4S95, D4S43, and D4S111 in HD and normal chromosomes.

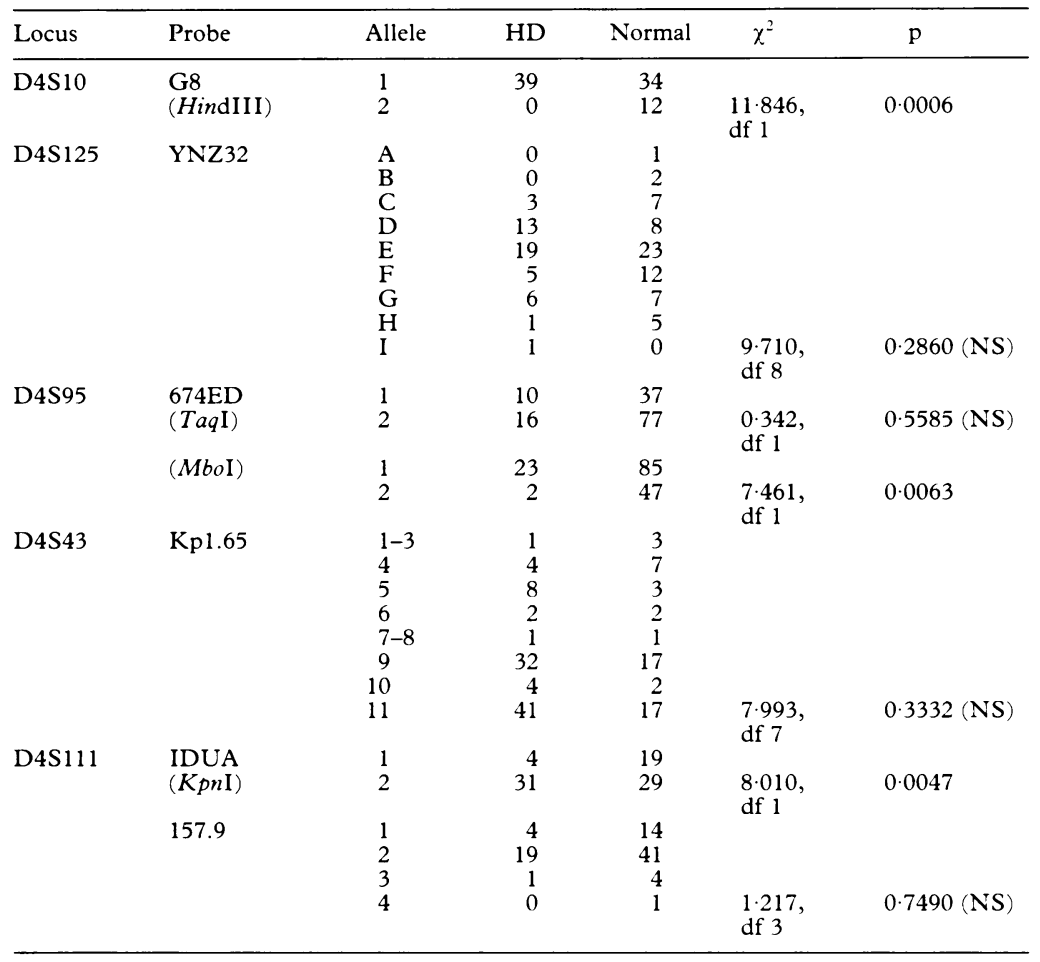

NS = not significant

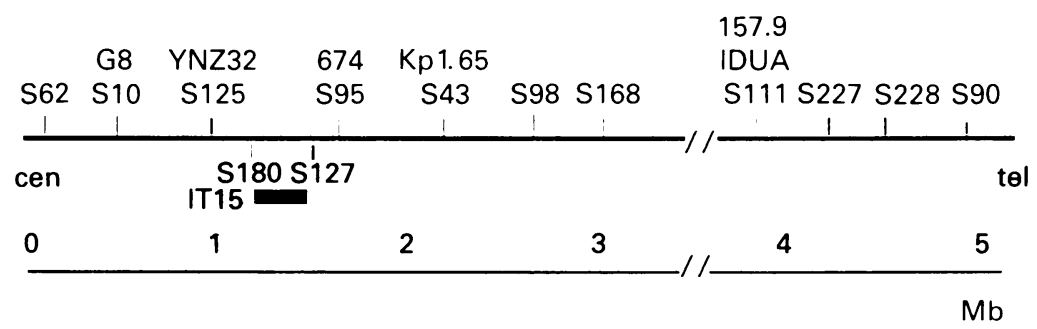

Figure 2 DNA markers around the HD gene locus on chromosome 4. The markers used in this study are shown above their appropriate locus number. The HD gene is marked with a bold line.
D4S10 and D4S228, together with evidence from haplotype analysis, ${ }^{8}$ imply that there are multiple origins of this triplet repeat expansion mutation and thus that HD has not originated from a single ancestral gene. More extensive haplotyping of HD chromosomes will now be possible because of the ability to determine repeat number in affected and at risk family members. This should enable more accurate regional $\mathrm{HD}$ haplotypes to be identified and help in localising founder origins of HD mutations in Europe and patterns of genetic drift.

PJM is supported by a Royal College of Physicians of Ireland Glaxo Fellowship in Molecular Biology. This work was supported in part by a grant from the Mental Health Foundation.

1 The Huntington's disease collaborative research group. A novel gene containing a trinucleotide repeat that is expanded and unstable on Huntington's disease chromosomes. Cell 1993;72:971-83.

2 Theilmann J, Kanani S, Shiang R, et al. Non-random association between alleles D4S95 and D4S98 and the Huntington's disease gene. F Med Genet 1989;26:676-81

3 Snell RG, Lazarou LP, Youngman S, et al. Linkage disequilibrium in Huntington's disease: an improved localisation for the gene. $\mathcal{F}$ Med Genet 1989;26:673-5.

4 Barron L, Curtis A, Shrimpton AE, et al. Linkage disequilibrium and recombination make a telomeric site for the Huntington's disease gene unlikely. $f$ Med Genet 1991;28:520-2.

5 Adam S, Theilmann J, Buetow K, et al. Linkage disequilibrium and modification of risk for Huntington disease. Am ₹ Hum Genet 1991;48:595-603.

6 MacDonald ME, Lin C, Srinidhi L, et al. Complex patterns of linkage disequilibrium in the Huntington disease reof linkage disequilibrium in the Huntingtc
gion. Am f Hum Genet 1991;49:723-34.

7 Nouvelletto A, Mandich P, Bellone E, et al. Non random association between DNA markers and Huntington disease locus in the Italian population. Am $\mathcal{f}$ Med Genet 1991;40:374-6.

8 MacDonald ME, Nouvelletto A, Lin C, et al. The Huntington's disease candidate region exhibits many different haplotypes. Nature Genet 1992;1:99-103.

9 Skraastad MI, Van de Vosse E, Belfroid R, et al. Significant linkage disequilibrium between the Huntington disease gene and the loci D4S10 and D4S95 in the Dutch population. Am $\mathcal{F}$ Hum Genet 1992;51:730-5.

10 Snell RG, Thompson LM, Tagle DA, et al. A recombination event that redefines the Huntington disease region Am F Hum Genet 1992;51:357-62.

11 Jeanpierre $M$. A rapid method for the purification of DNA from blood. Nucleic Acids Res 1987;15:9611.

12 Wasmuth JJ, Hewitt J, Smith B, et al. A highly polymorphic locus very tightly linked to the Huntington's disease gene. Nature 1988;332:734-6.

tions, suggesting a region of stability. All populations showing significant linkage disequilibrium with D4S95 ( $\mathrm{MboI}$ ) and D4S10 (HindIII) show an association with allele I. The Italian population ${ }^{7}$ and the Dutch population $^{9}$ also show linkage disequilibrium at the $\mathrm{D} 4 \mathrm{~S} 10$ locus, the latter over the region from D4S10 to D4S111, similar to our own study. Studies in mixed populations have shown linkage disequilibrium at D4S95 and also in the region $\mathrm{D} 4 \mathrm{~S} 133 / \mathrm{D} 4 \mathrm{~S} 228,3 \mathrm{Mb}$ telomeric to D4S95. ${ }^{20}$ The IT 15 (huntingtin) gene has been isolated from the region between the markers D4S180 and D4S127 (fig 2), adjacent to the locus D4S95, which has shown consistent linkage disequilibrium in all populations. However, regional variations in linkage disequilibrium identified at loci as distant as 